\title{
A RELIGIÃO NA TV: UM OLHAR SOBRE A REPRESENTAÇÃO DAS RELIGIÕES NAS TELENOVELAS DA REDE GLOBO
}

\author{
Jader Arantes Anunciação' \\ Kátia Zanvettor Ferreira ${ }^{2}$
}

Resumo: Este artigo tem como objetivo realizar um estudo exploratório da intersecção entre mídia e religião, enxergando o ponto de encontro dessas nas produções culturais produzidas e veiculadas pela televisão, suas motivações, olhares e interpretações e como ela apresenta suas concepções do Sagrado. Para tal, teremos como foco a representação das religiões nas telenovelas da TV Globo, consideramos esse produto como relevante pela abrangência do formato e a recorrência desse tema nos folhetins.

Palavras-chave: Telenovela; Televisão; Representação; Religião; Espiritismo.

${ }^{1}$ FCSAC/Universidade do Vale do Paraíba, Brasil. E-mail: jaderaarantes@gmail.com.

2 FCSAC/Universidade do Vale do Paraíba, Brasil. E-mail: katiazanvettor@univap.br. 